\title{
A Study of Competition and Concentration of Indian Mortgage (Housing) Finance using Herfindahl Model
}

\author{
D. V. Ingle*
}

\begin{abstract}
The growth in housing activities in recent years reflects the optimistic state of the housing finance market in the country. With a growing number of players, the mortgage (housing) finance sector is becoming market driven. The market has witnessed change in lending practices in certain segments to accommodate customer needs. There seems to be high intensity of competition among different players of the housing finance sector. The findings of the study reveal that the business of housing finance is highly concentrated in nature and revolves around a few players only. The top players are HDFC Limited, National Housing Bank, SBI, ICICI and LICHFL. Amongst these three HFIs, HDFC Limited is taking the lead. Talking about the value of HH index with respect to the level of concentration, the trend has continued to remain the same over several years. The performance of these institutions has been influenced by more than just customer demand. Stricter NPA norms, softening interest rates, and stiff competition in mobilizing low-cost deposits have all affected the supply-side factors, which in turn has influenced the performance of these institutions in terms of volume and competitiveness.
\end{abstract}

Keywords: Housing Finance, Housing Finance Companies, Herfindahl Hirschman Index, Marketing and Concentration.

\subsection{Introduction}

Housing finance sector has enough competencies to provide employment at large. The accelerated growth of housing finance sector has acquired a prominent place in India's GDP. The housing credit in percentage of GDP has risen from 2.5\% in 2003 to $7.00 \%$ in 2009. Since then it is constant and is now expected to be $6 \%$ during the current year. There is an extended reach of financial market to serve the housing needs across different regions and different segments of the population.

*Assistant Professor, Smt. L. R. T. College Of Commerce, Maharashtra. 
2 | MANTHAN: Journal of Commerce and Management, Vol. 2, Issue 2

With an increase in the disposable income of the people, changes are taking place in the economy and there is an increased demand for housing. The Housing Finance Institutions (HFIs) have seen good value in funding this component of economy. The Government is making continuous efforts to improve housing conditions by way of financial allocations. In an ICRA study, the Indian housing finance market has crossed the Rs. 10 trillion mark as on December 31, 2014, indicating a steady growth of $17 \%$ (annualized) for 9 months for the year 2015. Of this, Rs.10 trillion housing loan book, Rs 6.3 trillion loan is with the banking sector and the balance RS 3.7 trillion with HFCs and NBFCs. The market continues to be dominated by the five large institutions namely SBI Home, HDFC, LIC Housing Finance, ICICI Home and National Housing Bank, accounting for $70 \%$ of the total housing credit in India.

The housing finance market in India could expand to borrowers who are currently not being serviced by financial institutions specifically the borrowers in low-tomiddle income segment and may not have formal income proof. On the supply side, various state governments have introduced initiatives to encourage developers to launch projects in the affordable housing space. On the funding front, steps like recent advisory by PMO to EPFO for investing $15 \%$ of their funds towards low cost housing and RBI allowing banks to raise long-term bonds for affordable housing segment with relaxations on CRR (Cash reserve ratio) and SLR (Statutory Liquidity Ratio) requirements, could improve the fund to this segment. Thus it leads to significant potential for growth in the housing market. In addition to this, with a favourable demographic profile, the mortgage (housing) finance industry in India is expected to grow at around $19-21 \%$ year on year.. Consequently, mortgage penetration which is currently at 5-6\% could increase to double digits over the years. As for the funding mix, the HFCs have a diversified funding base with larger players being more active in the debt market and their smaller counterparts relying more on bank funding and NHB refinance. Entry of commercial bank in housing space and direct lending to individuals for housing schemes led to increased competition.

\subsection{Literature Review}

A few studies concerning the competition in housing finance industry are available in the Indian context. Vora (1999) highlighted the key issues in the development of the housing finance sector. The Government of India has considered development of the housing sector a priority, both from the demand and the supply side. According to Renu Karnad (2004) housing finance system in India is facing intense competition and in consumer-oriented market HFCs follows aggressive pricing strategies. 
Biyani and Krishnan (2004) focused on how housing finance institutions are ethically and morally correct in promoting risky products without providing the consumers with adequate information. Their study reveals that banks and HFCs are luring customers by cutting down their interest rates and aggressively selling their products with floating interest rates.

Rao (2006) has explained that the housing finance in India, the market has grown tremendously. The availability of tax shelter on repayment of principal and interest attracts the borrowers. Green and Wachter (2007) have explained in their paper that housing finance market has undergone dramatic changes in recent years. Due to the development of capital market, securitisation funding for housing comes from a much broader set of investors. The paper has examined that institutional changes have taken place in housing finance in industrialised countries over the past 30 years.

Tiwari (2011) conducted a research on development of housing finance in India. The study reveals that housing finance sector in India has undergone radical changes and it is expected that housing finance sector in India will undergo second revolution, due to huge demand estimates. Santosh (2011) conducted a research on growth and development of housing in post liberalization period. The study shows that although the housing finance sector is flooded with a number of institutions yet there are certain developments which are waiting to take place. Companies have not been able to penetrate into rural areas. A large section of Indian society is still out of preview of HFIs and this aspect needs to be developed. Shah and Aggarwal (2012) prepared a report on Indian Housing Finance. The report highlights the favorable growth environment that is giving strong demand drivers as well the improving demographics. The report analyses the performance of three major housing finance institutions, i.e. Dewan Housing Finance, HDFC Limited and LIC Housing Finance.

\subsection{Need for the Study}

In the competitive world, result oriented performance is the key of survival. The review of literature shows that a number of studies have been conducted relating to the housing finance sector which are based either on the case study of a particular institution or on the performance appraisal of housing finance system in general. However, few attempts have been made yet to study the competitive dynamics of HFIs. To fill this gap in the existing literature, this study analyses the competition prevailing amongst the selected HFIs.

\subsection{Objectives of the study}

The objectives of the study are as follows: 
4 | MANTHAN: Journal of Commerce and Management, Vol. 2, Issue 2

i) To study and analyse the level of concentration of competition amongst selected HFIs.

ii) To identify the trend of concentration of competition across years.

\subsection{Data and Sample}

For the purpose of study, data from the 2009-10 to 2013-2014 has been used for measuring the competitive dynamics of sample HFIs. The companies for analysis have been selected from the list of companies approved by the National Housing Bank and which have been given permission to accept public deposits and listed with recognized stock exchange. For measuring the competition among selected companies, data for five year i.e.2009- 2010 to 2013-2014 has been taken. Ten housing finance institutions having about 70 percent share in the home finance market have been selected for study (Table 1).

Table 1: Sample of Housing Finance Institutions

\begin{tabular}{|c|l|c|l|}
\hline S. No. & \multicolumn{1}{|c|}{ Institutions } & S. No. & \multicolumn{1}{|c|}{ Institutions } \\
\hline 1 & HDFC & 6 & Gruh Finance \\
\hline 2 & Can-Fin homes & 7 & LIC Housing Finance \\
\hline 3 & PNB housing & 8 & GIC Home Finance \\
\hline 4 & Dewan Housing Finance & 9 & ICICI Home \\
\hline 5 & National Housing Bank & 10 & SBI Home \\
\hline
\end{tabular}

Data sources: For the purpose of measuring the competition in housing finance segment, market share of sample institutions in the housing loan portfolio has been used. In case of major players of Housing finance like banks, Housing finance companies (HFC's) and National Housing bank's loan portfolio and housing loan market share has been taken as base. A study of the 10 HFIs was done for a period of 5 years, i.e. from 2009-2010 to 2013-2014. The main source of data is secondary, i.e. published annual reports of the HFIs.

\subsection{Scope and limitations}

10 housing finance institutions have been selected for the study. There are other home finance institutions prevailing in the market which are not covered in the study. While calculating the market share decimal more than 0.5 is converted to next round figure. 


\subsection{Profile of Sample Housing Finance Institutions}

\section{Housing Development Finance Corporation Limited}

HDFC's distribution network spans 378 outlets, which include 87 offices of the wholly owned distribution company, HDFC Sales Private Limited (HSPL). In addition, HDFC covers several locations through outreach programmes in line with the limits set out by the Board of Directors. This institution is the leader in the sector of housing finance and the hold major i.e. $29 \%$ of market share.

\section{Can-Fin Homes}

Can-Fin Homes Ltd set up under the sponsorship of Canara Bank and is the first housing company to be promoted by a nationalised bank in India. The company is having 109 branches and 26 satellite offices spread across various locations of the country and all these branches and satellite offices are linked to the Registered Office at Bangalore through a core banking platform. Being a south based company, $70 \%$ of its branches are located in southern India and the remaining 30\% in Northern India. The Company is a housing finance institution approved by National Housing Bank (NHB). The Company is offering a range of loan products, housing loans as well as non-housing loans, at competitive interest rates and designed to suit the needs of the customer.

\section{PNB Housing Finance Limited}

PNB Housing Finance Limited (PNBHFL) is a registered housing finance company with National Housing Bank (NHB). PNBHFL is a subsidiary of Punjab National Bank (PNB), which holds $51 \%$ of share capital in the Company. With over two decades of specialized experience in housing finance, PNBHFL has a robust network of branches spread across the country which help its customers avail financial services (loans and deposits) flawlessly. PNBHFL provides housing loans to individuals and corporate bodies for construction, purchase and up gradation of houses.

\section{Dewan Housing Finance Corporation Limited}

Founded in 1984, DHFL is the second largest housing finance company in India's private sector, with a vision to transform the lives of every Indian household by enabling access to home ownership with presence across 450 locations. The Company also has representative offices at Dubai and London. DHFL being the second largest player in the housing finance industry is well placed to benefit from continued growth in India's mortgage market. DHFL enjoys several long-term earnings growth drivers: (1) Strong presence in relatively less competitive tier-II and tier-III cities, (2) Presence 
6 | MANTHAN: Journal of Commerce and Management, Vol. 2, Issue 2

across the income spectrum, (3) Widespread reach, (4) Robust asset quality, (5) stable cost of funds etc. This company has extension network all over India with 35 camps, 78 service centers and 74 branches in different parts of the country. Thus, these companies enable people to get their dream of own house come true!

\section{National Housing Bank}

National Housing Bank (NHB), a wholly owned subsidiary of Reserve Bank of India (RBI), was set up on July 9, 1988 under the National Housing Bank Act, 1987. NHB is an apex financial institution for housing. NHB has been established with an objective to operate as a principal agency to promote housing finance institutions both at local and regional levels and to provide financial and other support incidental to such institutions and for matters connected therewith. NHB registers, regulates and supervises Housing Finance Company (HFCs), keeps surveillance through On-site \& Off-site Mechanisms and co-ordinates with other Regulators.

\section{GRUH Finance}

HDFC holds approx. 59\% in GRUH. It is a housing finance company offering loans to individuals for purchase, construction and renovation of dwelling units. It also offers loans to the self-employed segment where formal income proofs are not available. It has a retail network of 136 offices across 7 states in India. Gruh Finance (Formerly Gujarat Rural Housing Corporation Limited) was set up in 1986 by HDFC with the objective of providing institutional structure to rural housing finance. HDFC owns around $60 \%$ stake in the company and provides it equity support. Gruh's major focus is to provide home loans to individuals and families for purchase, construction and extension. It also provides loan for repair and renovation of houses. The company has a distinct target market segment, which complements HDFC's market. This segment is distinct from HDFC's target segment. GRUH also cross sells HDFC products.

\section{LIC Housing Finance Limited}

(LIC HFL) is one of the largest Housing Finance Company in India having its Registered and Corporate office at Mumbai. The Company provides long term finance to persons engaged in the business of construction of houses or flats for residential purpose and to be sold by them. It has 7 regional offices, 16 back-offices and 222 marketing units across India. It also has offices in Kuwait and Dubai to cater to the Non-Resident Indians in the Gulf countries covering Bahrain, Dubai, Kuwait, Qatar and Saudi Arabia. 


\section{GIC Housing Finance Limited}

The primary business of GICHFL is granting housing loans to individuals and to persons and entities engaged in construction of houses and flats for residential purposes. GICHFL has presence in 42 branches across the country for business. It has a strong marketing team, which is further assisted by Sales Associates (SAs). It has tie-ups with builders to provide finance to individual borrowers. It also has tie-ups with corporate for various housing finance needs.

\section{ICICI Home}

ICICI Home Finance Company is wholly owned subsidiary of ICICI Bank. The Company is engaged in providing financial assistance for specified interest \& maturity to persons for the purpose to acquire, construct, erect, improve, extend, alter, repair, renovate, develop any house, flats or buildings or any form of real estate or any part or portion thereof. The Company is also providing financial assistance to any person for specified purpose against the security of any immovable property. The Company is also engaged in providing advisory, consultancy, broking in property service, sourcing and servicing home loans. It further said ICICI Bank's mortgage business is primarily done within the bank and this business has been growing rapidly.

\section{State Bank Home}

State Bank of India is Indian multinational, public sector banking and financial services institution. It had assets of US $\$ 388$ billion and 17,000 branches, including 190 foreign offices, making it the largest banking and financial services company in India by assets. SBI has 14 regional hubs and 57 Zonal Offices that are located at important cities throughout India. SBI is one of the largest employers in the country having 222,033 employees as on 31 March 2014 providing housing loan in the market.

\subsection{Issue of Competitive Dynamics}

There is aggressive campaign on the part of banks and HFCs to provide home loans to more and more customers. These HFCs are adopting aggressive strategies like tele-marketing, engaging direct sales agents, conducting exhibitions and loan melas. The financiers are more willing to finance the entire house, even including the furnishings. The biggest reason for the surge in home loans is the supply side economics. 'Banks are flush with funds, and they find it attractive to lend in the mortgage market'. Historically, this segment had a very low rate of non-performing assets below 1 per cent and that is an added attraction. Banks and financial institutions have brought a radical change in their 
8 | MANTHAN: Journal of Commerce and Management, Vol. 2, Issue 2

strategies and there is a clear shift from sellers' market to buyers' market. The main features of these loan schemes are consumer flexibility, adjustable rate plans, lower processing fees, low equated monthly installment (EMI), lower margin money, no prepayment penalty, etc. Many of the players of housing finance have offered some addons with their loan plans such as life insurance, credit card, and consumer loans. Some of the players have offered tailor-made loan schemes for repair, renovation, extension, conversion, improvement, waterproofing, roofing, painting, plumbing and electrical work, tiling, flooring, and grilling, etc. In order to increase the market share, lending institutions are competing with each other by offering very attractive terms to customers in the form of lower rate of interest, liberal collateral requirements, longer repayment period, or a very high loan to value (LTV) ratio which at times goes up to or even beyond 100 per cent of the value of the house including the cost of land. Acute competition has made 'housing finance at doorstep' possible with customers having a wide variety to choose from.

All this shows that there seems to be a high intensity of competition among different players of the housing finance industry. But this competition needs to be measured to observe its intensity and understand the competitive dynamics of housing finance to make it more consumer-friendly and favorable to industry as well. As in other industries, the degree of competition in the housing finance sector can matter for the efficiency of the production of housing finance services, the quality of housing financial products and the degree of innovation in the sector.

\subsection{Analysis and Interpretation}

\subsection{Housing Loan Portfolio}

The housing loan portfolio of housing finance institutions in the market has been explained the Table 2. The table shows that HDFC has highest loan portfolio during the study periods, followed by SBI Home, National Housing bank, LIC Home Finance, ICICI and Diwan Housing finance. These housing finance institutions have major market share in loan segment.

\subsection{Housing Loan Market Share}

The housing loan market share of housing finance institutions is shown in Table 3. As per the loan portfolio of the housing finance institutions during study periods market share has been calculated. The market share has been calculated using the formula- 


$$
\text { Marketshare }=\frac{\text { Institutions Loan Portfolio }}{- \text { Total Loan Portfolio }} \text { X } 100
$$

Table 2: Housing Loan Portfolio in the Home Loan Market

\begin{tabular}{|c|c|c|c|c|c|c|}
\hline \multirow[b]{2}{*}{$\begin{array}{l}\text { S. } \\
\text { No. }\end{array}$} & \multirow[b]{2}{*}{ Institutions } & 2009-10 & $2010-11$ & 2011-12 & 2012-13 & 2013-14 \\
\hline & & $\begin{array}{c}\text { Loan } \\
\text { Portfolio }\end{array}$ & $\begin{array}{c}\text { Loan } \\
\text { Portfolio }\end{array}$ & $\begin{array}{c}\text { Loan } \\
\text { Portfolio }\end{array}$ & $\begin{array}{c}\text { Loan } \\
\text { Portfolio }\end{array}$ & $\begin{array}{c}\text { Loan } \\
\text { Portfolio }\end{array}$ \\
\hline 1 & HDFC & 97,966 & $1,17,126$ & $1,40,874$ & $1,70,046$ & $1,97,100$ \\
\hline 2 & Can. Fin. homes & 2,106 & 2,207 & 2,674 & 4,016 & 5,844 \\
\hline 3 & PNB Housing & 2,507 & 3,167 & 3,970 & 6,620 & 5,550 \\
\hline 4 & Dewan Home Finance & 13,234 & 19,739 & 28,805 & 42,162 & 58,810 \\
\hline 5 & National Housing Bank & 58,974 & 70,697 & 85,087 & $1,02,629$ & $1,20,485$ \\
\hline 6 & Gruh Finance & 2,454 & 3,177 & 4,067 & 5,438 & 8,915 \\
\hline 7 & LIC Housing Finance & 38,081 & 51,090 & 63,080 & 77,812 & 91,341 \\
\hline 8 & GIC Home Finance & 2,931 & 3,416 & 3,871 & 4,539 & 6,425 \\
\hline 9 & ICICI Home & 57,588 & 71,244 & 73,528 & 65,152 & 77,074 \\
\hline 10 & SBI Home & 54,063 & 62,713 & $1,02,739$ & $1,19,889$ & $1,40,738$ \\
\hline & Total & $3,29,904$ & $4,04,576$ & $5,08,695$ & $5,99,627$ & $7,14,463$ \\
\hline
\end{tabular}

Source: Annual Reports of Housing Finance Institutions

Table 3: Housing Loan Market Share in the Home Loan Market

\begin{tabular}{|c|l|c|c|c|c|c|}
\hline \multirow{2}{*}{$\begin{array}{c}\text { S. } \\
\text { No. }\end{array}$} & \multicolumn{1}{|c|}{ Institutions } & $\mathbf{2 0 0 9 - 1 0}$ & $\mathbf{2 0 1 0 - 1 1}$ & $\mathbf{2 0 1 1 - 1 2}$ & $\mathbf{2 0 1 2 - 1 3}$ & $\mathbf{2 0 1 3 - 1 4}$ \\
\cline { 3 - 7 } & & $\begin{array}{c}\text { Market } \\
\text { Share } \\
\mathbf{\%}\end{array}$ & $\begin{array}{c}\text { Market } \\
\text { Share } \\
\mathbf{\%}\end{array}$ & $\begin{array}{c}\text { Market } \\
\text { Share } \\
\mathbf{\%}\end{array}$ & $\begin{array}{c}\text { Market } \\
\text { Share } \\
\mathbf{\%}\end{array}$ & $\begin{array}{c}\text { Market } \\
\text { Share } \\
\mathbf{\%}\end{array}$ \\
\hline 1 & HDFC & 29 & 29 & 22 & 28 & 28 \\
\hline 2 & Can. Fin. homes & 01 & 01 & 01 & 01 & 01 \\
\hline 3 & PNB Housing & 01 & 01 & 01 & 01 & 01 \\
\hline 4 & Dewan Home Finance & 04 & 05 & 07 & 07 & 08 \\
\hline 5 & National Housing Bank & 18 & 17 & 19 & 17 & 16 \\
\hline 6 & Gruh Finance & 01 & 01 & 01 & 01 & 01 \\
\hline 7 & LIC Housing Finance & 11 & 13 & 12 & 13 & 13 \\
\hline 8 & GIC Home Finance & 01 & 01 & 01 & 01 & 01 \\
\hline 9 & ICICI Home & 17 & 17 & 15 & 11 & 11 \\
\hline 10 & SBI Home & 17 & 15 & 21 & 20 & 20 \\
\hline & Total & $\mathbf{1 0 0}$ & $\mathbf{1 0 0}$ & $\mathbf{1 0 0}$ & $\mathbf{1 0 0}$ & $\mathbf{1 0 0}$ \\
\hline
\end{tabular}




\subsection{Application of Herfindahl Index}

The Herfindahl Index also known as Herfindahl-Hirschman or HHI model is a measure of the size of firms in relation to the industry and an indicator of the amount of competition among them. It is defined as the sum of the squares of the market share of the firms within the industry, where the market shares are expressed as fractions. The result is proportional to the average market share, weighted by market share. Increases in the Herfindahl index generally indicate a decrease in competition and an increase of market power, whereas decreases indicate the opposite. The major benefit of the Herfindahl index in relationship to such measures as the concentration ratio is that it gives more weight to larger firms.

$$
\mathrm{H}=\sum_{I=1}^{N} S_{\mathrm{i}}^{2}
$$

where $s_{i}$ is the market share of firm $i$ in the market,

The Herfindahl Index $(H)$ ranges from $1 / N$ to one, $N$ is the number of firms in the market i.e. 10.

An $\mathrm{H}$ between 1,500 to 2,500 indicates moderate concentration.

An $\mathrm{H}$ above 2,500 indicates high concentration.

A higher Herfindahl signifies a less competitive industry.

The results of the HH index calculation are shown in Table 4.

\subsection{Analysis and result}

The level of concentration and competition among the major players of housing finance can be studied from Table 2 and 3, which shows the housing loan portfolio of these players over the years along with percentage of their market share in housing finance. By using these percentages of share in the total disbursements $\mathrm{HH}$ index has been computed. If we look at the value of $\mathrm{HH}$ Index in Table 4, initially the index is 1884 in the year 2009-10 which decreased subsequently and it is stable for last two years from 2012-13 to 2013-14. As far as the degree of competition among the players is concerned the increase in the competition is not much encouraging. This is because of lowering of the share of housing finance companies as major players of housing finance. Their share in the total disbursements has almost all constant during study period. The national housing banks portfolio is also constant. The trends in the market are making banking sector more powerful because of their large network and potentiality in working. The value of HH Index shown in the table also indicates the high level of concentration because in all the years the value is more than 1800 which means high level of concentration during 2009-10 to 2010-11. Thereafter there is slightly decreasing in $\mathrm{HH}$ index which indicate high concentration. 
Table 4: Calculation of Herfindahl-Hirshman Index

\begin{tabular}{|c|c|c|c|c|c|c|c|c|c|c|}
\hline \multirow[t]{2}{*}{ Institutions } & \multicolumn{2}{|c|}{$2009-10$} & \multicolumn{2}{|c|}{$2010-11$} & \multicolumn{2}{|c|}{ 2011-12 } & \multicolumn{2}{|c|}{$2012-13$} & \multicolumn{2}{|c|}{$2013-14$} \\
\hline & $\begin{array}{c}\text { Market } \\
\text { share } \\
\% \\
\text { A }\end{array}$ & $\mathrm{A}^{2}$ & $\begin{array}{c}\text { Market } \\
\text { Share } \\
\% \\
\text { B }\end{array}$ & $\mathrm{B}^{2}$ & $\begin{array}{c}\text { Market } \\
\text { Share } \\
\% \\
\text { C }\end{array}$ & $\mathrm{C}^{2}$ & $\begin{array}{c}\text { Market } \\
\text { Share } \\
\% \\
\text { D }\end{array}$ & $\mathrm{D}^{2}$ & $\begin{array}{c}\text { Market } \\
\text { Share } \\
\% \\
\text { E }\end{array}$ & $E^{2}$ \\
\hline HDFC & 29 & 841 & 29 & 841 & 22 & 484 & 28 & 784 & 28 & 784 \\
\hline $\begin{array}{l}\text { Can. Fin. } \\
\text { homes }\end{array}$ & 01 & 1 & 01 & 1 & 01 & 1 & 01 & 1 & 01 & 1 \\
\hline $\begin{array}{l}\text { PNB } \\
\text { housing }\end{array}$ & 01 & 1 & 01 & 1 & 01 & 1 & 01 & 1 & 01 & 1 \\
\hline $\begin{array}{l}\text { Dewan } \\
\text { Home } \\
\text { Finance }\end{array}$ & 04 & 16 & 05 & 25 & 07 & 49 & 07 & 49 & 08 & 64 \\
\hline $\begin{array}{l}\text { National } \\
\text { Housing } \\
\text { Bank }\end{array}$ & 18 & 324 & 17 & 289 & 19 & 361 & 17 & 289 & 16 & 259 \\
\hline $\begin{array}{l}\text { Gruh } \\
\text { Finance }\end{array}$ & 01 & 1 & 01 & 1 & 01 & 1 & 01 & 1 & 01 & 1 \\
\hline $\begin{array}{l}\text { LIC } \\
\text { Housing } \\
\text { Finance }\end{array}$ & 11 & 121 & 13 & 149 & 12 & 144 & 13 & 149 & 13 & 149 \\
\hline $\begin{array}{l}\text { GIC Home } \\
\text { Finance }\end{array}$ & 01 & 1 & 01 & 1 & 01 & 1 & 01 & 1 & 01 & 1 \\
\hline ICICI Home & 17 & 289 & 17 & 289 & 15 & 225 & 11 & 121 & 11 & 121 \\
\hline SBI Home & 17 & 289 & 15 & 225 & 21 & 441 & 20 & 400 & 20 & 400 \\
\hline $\begin{array}{l}\text { Herfindahl- } \\
\text { Hirshman } \\
\text { Index }\end{array}$ & & 1884 & & 1822 & & 1708 & & 1796 & & 1781 \\
\hline
\end{tabular}

Source: Primary Calculations on the basis of Housing Loan Portfolio

Concentration level among the major housing finance companies can also be studied from Table 4, which shows the disbursements of the top 10 housing finance companies registered with the National Housing Bank (NHB) as per Section 29A of the NHB Act and are eligible to accept public deposits. This shows that five major players HDFC, National Housing Bank, ICICI, SBI and LICHF are enjoying the major share of housing finance business. This is because of their national character. Other housing finance companies are either working regionally or their reach is limited. The value of HH Index also shows the high level of concentration, and also that HDFC is representing as the major player in the formal system of housing finance among housing finance companies.

$\mathrm{HH}$ Index is calculated on the basis of total assets of leading Housing finance companies (HFCs). The HH Index also shows steady trend and average index comes out to be which is also rated as very high, displaying increasing concentration and 
competitiveness. The entry of banking institutions has compelled the housing finance companies to reinvent their areas of core competence. The phenomenon has brought significant change in the structure of housing finance system in India. As a result of aggressive competition from banks and gradual softening of rate of interest, the HFCs are compelled to operate within a lower spread. Stiff competition in housing finance market has made the functioning of many of the small player unviable. These consolidations in housing finance market pointed to the fact that functioning of small HFCs is very much under pressure. Many small private HFCs without strong parent backing are gradually losing their market share. HFCs have higher cost of funds as compared with banks as they depend on priority sector, sub-PLR loans from banks, fixed deposits, NHB refinance, and in some cases low-cost loans from multilateral agencies. Most private HFCs (excluding HDFC) do not enjoy the highest investment grade ratings by credit rating agencies, which further increase their cost of funds. As a result, HFCs, in general, either have lower spread as compared with banks or are not able to match rates with banks. the housing finance companies approved by the National Housing Bank are performing well, others are not showing any sign of progress.

\subsection{Conclusion}

The findings of the study reveal that the business of housing finance is highly concentrated in nature and revolves around a few players only. The top players are HDFC Limited, National Housing Bank, SBI, ICICI and LICHFL. Amongst these three HFIs, HDFC Limited is a leader in the market. Rests of the players are contributing relatively less. Talking about the value of $\mathrm{HH}$ index with respect to the level of concentration, the value has remained far above the standards prescribed. The trend has continued to remain the same over several years. The performance of these institutions has been influenced by more factors than just demand of customer. Stricter NPA norms, softening interest rates, and stiff competition in mobilizing low-cost deposits have all affected the supply-side factors, which in turn has influenced the performance of these institutions in terms of volume and competitiveness. Thus, healthy competitiveness in the field of housing finance will be beneficial for customer.

\section{References}

Bhalla, Ashwani Kumar \& Arora, Parvinder (2009). Competitive Dynamics of Indian Housing Finance Industry. Paradigm, 12(1), January-June: 28-38. 
Brar, Jasmindeep Kaur; \& Pasricha, J.S, (2000). Housing Loans A Comparative Study of Institutions, The Indian Journal of Commerce, 58(2): 71-79.

Gupta, Parveen (2005), Housing Finance Companies--An Insight into Regulatory Aspects, The Chartered Accountant: 1010-1015.

Garg, Yogendra Kumar, (2002). New directions in Asian housing finance, Linking Capital Market and Housing Finance, Washington DC: IFC, Ch. 4: 83-111.

Government of India, (1996), Housing Finance Institutions Directory, New Delhi: NBO: 18.

Misra, P.C. (2001). Housing Finance: A step towards Housing for all. Facts for You, 22(2): 28-31.

Prashat, Mahesh, (1998). Housing Finance: Safe and Steady, Express Investment Week, 8(4): 16-21.

Vora, P.P. (1999). The Indian Housing Finance System, Housing Finance International: $18-25$. 